Dochody imigrantów i ich transfery zagraniczne, red. Magdalena Butrymowicz,

Piotr Kroczek, Kraków 2019, s. 5-17 (Biblioteczka Prawa 3).

DOI: http://dx.doi.org/10.15633/9788374387804 .01

Magdalena Butrymowicz

OOOO-0002-9920-5860

UNIWERSYTET PAPIESKI JANA PAWŁA II W KRAKOWIE

\title{
Prawa obywatela a prawa cudzoziemca? Dylemat państwa XXI wieku
}

Wiek Xxi to wiek masowej emigracji ludności Azji i Afryki do Europy oraz mieszkańców Ameryki Południowej do Ameryki Północnej. Historycznie patrząc, nie jest to zjawisko nowe, wcześniej światu nieznane. Można je porównać do masowej wędrówki ludów w viI wieku, kiedy to uciekając przed naporem wędrownych ludów Wschodu plemiona germańskie czy słowiańskie zaczęły masowo przemieszczać się na tereny kontrolowane przez Cesarstwo Rzymskie i osiedlać się w jego granicach. Efektem wędrówki ludów był upadek Cesarstwa Rzymskiego i powstanie państwa Franków, z którego wyłoniły się następnie Francja i Hiszpania ${ }^{1}$. Europa, przynajmniej w świetle danych statystycznych, swój największy kryzys emigracyjny przeżyła w 2017 roku i nadal boryka się z niespotykaną do tej pory falą emigrantów. Państwa przyjmujące lub państwa docelowe oprócz problemów ekonomicznych i organizacyjnych coraz częściej napotykają sprzeciw swoich obywateli, którzy przestają

1 S. Grodziski, Porównawcza historia ustrojów państwowych, Kraków 1998, s. 13-18. 
akceptować politykę państwa i powołują się na swoją pozycję obywateli, podkreślając odmienny status emigrantów jako gości w ich państwie.

Zaistniał zatem w państwie wewnętrzny konflikt pomiędzy nowo przybyłym człowiekiem określanym jako emigrant a tym, który od znacznie dłuższego czasu zamieszkuje w granicach państwa lub nawet może udowodnić pewną historyczną ciągłość swojego pobytu na określonym terytorium. Samo państwo rozróżnia także te dwie jednostki ludzkie poprzez przyznanie określonego katalogu praw wyłącznie obywatelom, a emigrantom prawa ograniczone. Takie podejście państwa wydaje się w pełni uzasadnione. Problem pojawia się jednak wtedy, gdy emigrant zaczyna wskazywać na źródło swoich praw, czyli normę międzynarodową, domagając się zrównania z prawami obywatela. Z drugiej strony jednak prawa człowieka mają charakter uniwersalny, każda osoba ma prawo do pełnego korzystania z przywilejów, jakie dają prawa człowieka, w każdym aspekcie jego życia, szczególnie zaś w zakresie praw podstawowych, takich jak prawo do życia, prawo do posiadania mieszkania, prawo do uczestniczenia w życiu politycznym kraju, w którym zamieszkuje. W kategorii praw człowieka każdy jest równy, każdy posiada określone prawa i nie ma podziału na ludzi pierwszej idrugiej kategorii ${ }^{2}$.

\section{Państwo a obywatel}

W ogólnym odczuciu społecznym obywatelstwo jest postrzegane jako wartość sama w sobie, warunek i potwierdzenie istnienia określonego katalogu praw czy przynależności. Większość państw na świecie wprowadza na poziomie szkoły podstawowej obowiązkową edukację o państwie i obywatelstwie. Dzieci zatem od samego początku są uczone praw

2 J. Martenson, The United Nations and Human Rights Today and Tomorrow, [w: Human Rights in the Twenty - First Century: a Global Challenge, part 2, ed. K. E. Mahoney, P. Mahoney, Dordrecht-Boston-London 1993, s. 926-927. 
i obowiązków obywatela w państwie, którego obywatelstwo posiadają. Rodzice także dążą do tego, aby ich dzieci mogły legitymować się obywatelstwem określonego kraju ich pochodzenia oraz ich zamieszkania. Czym zatem jest obywatelstwo w rozumieniu prawnym i społecznym?

Istniejący obecnie system ochrony praw człowieka powstał w czasie obrad Pokojowej Konferencji w Hadze w 1899 roku, kiedy zostały przyjęte do dziś obowiązujące zasady międzynarodowego prawa humanitarnego oraz prawo wojny. Podstawą systemu praw człowieka jest bowiem prawo humanitarne, $\mathrm{w}$ tym zasady regulujące prawo przebiegu wojny, humanitaryzm wojny i prawo chroniące człowieka jako jednostkę ludzką. Właśnie w Hadze pojawił się koncept ochrony jednostki jako podmiotu słabszego przed naciskiem państwa. Państwa podjęły decyzję o ograniczeniu swojej suwerenności w ten sposób, iż przyznały obywatelom określony katalog praw i przywilejów i zobowiązały się go przestrzegać. Fundamentem praw człowieka jest bowiem to, iż państwa potrzebę ochrony praw człowieka (ideę humanitaryzmu) przedkładają nad potrzebę ochrony swej suwerenności poprzez akomodację zasady, iż państwo ma służyć swoim obywatelom, a nie obywatele państwu³. Państwo narodowe bowiem to państwo stanowiące własność ludzi, źródłem prawa i fundamentem istnienia państwa są zatem jego obywatele.

Obywatelstwo jest zatem powiązane z określonym terytorium, na którym władztwo sprawuje państwo, i z poczuciem przynależności do określonego narodu, gdzie interes obywatela znaczy więcej niż interes cudzoziemca, który razem z nim przebywa na terytorium określonego państwa. W powszechnym odczuciu prawa i dobro obywatela powinny dominować nad interesem cudzoziemców. Według tradycyjnego podejścia do obywatelstwa obywatel powinien wykazywać się pełną lojalnością wobec państwa, w którym zamieszkuje, i powinien identyfikować się

3 R. Normand, S. Zaidi, Human Rights at the UN. The political History of Universal Justice, Bloominton 2008, s. 35-38. 
wyłącznie z jednym narodem. Współcześnie trwa jednak dyskusja nad statusem prawnym obywatelstwa i jego charakterem. Modernistyczne podejście odrywa obywatelstwo od przynależności narodowej, cytując język praw człowieka, iż obywatelstwo jest prawem, a nie przywilejem ${ }^{4}$.

Niemniej jednak państwo, zgodnie z każdą definicją prawną, to zamieszkujący go lud, bez którego państwo po prostu nie może istnieć. Określona społeczność zamieszkuje bowiem pewne terytorium, które jest przez nią kontrolowane. Przyjmując szeroką definicję obywatelstwa, oderwaną od wymiaru narodowości, założyć należy, iż każda osoba przebywająca na terytorium państwa jest jego obywatelem. Takie założenie jest postrzegane przez państwo jako powodujące zagrożenie dla jego bezpieczeństwa i integralności. Ważne zatem staje się prawidłowe zdefiniowanie terminu „ludność, lud”. Dla niektórych badaczy słowo „lud” jest w całości połączone z założeniem, iż jest to jakiś twór, jakaś społeczność obywateli, których łączy specyficzna odmienność od innej społeczności w zakresie ich etnicznego pochodzenia i politycznych zdolności. Stwierdzenie w konstytucji: „my, ludzie”, zawsze zakłada istnienie jakiegoś obcego podmiotu, jakiegoś cudzoziemca, który z założenia jest wyłączony z tej wspólnoty. Ludzie-obywatele są zatem grupą wyjątkową. Lud to wspólnota polityczna, połączona niekiedy węzłami krwi, przywiązaniem do określonego terytorium, posługująca się wspólnym językiem5. Państwo zatem z założenia chroni lud, któremu przyznało prawo do posiadania obywatelstwa. W odczuciu państwa to obywatelstwo pełni dwie ważne funkcje: obronną (obywatel w relacji do państwa) oraz jako broń (państwo w relacji do nie-obywateli). Rolę obronną obywatelstwo pełni w przypadku deportacji, obrony tożsamo-

4 D. Kostakopoulou, The Future Governance of Citizenship, New York 2008, s. 1-3.

5 S. Fiedler, Global or national? Between the multitude and the people, w: Nationalism and Global Solidarities: Alternative Projections to Neoliberal Globalisation, ed. J. Goodman, P. James, London-Nowy Jork 2006, s. 56-57 (Routledge Studies in Globalisation Book, 15) . 
ści narodowej (kiedy to obywatelstwo promuje określoną etnicznie grupę lub naród), obrony nabytej tożsamości |(obywatelstwo jest bowiem przedmiotem dziedziczenia, tak jak rasa czy przynależność narodowa, z tym iż można się go zrzec, co jest niemożliwe w przypadku rasy czy narodowości). Obywatelstwo w perspektywie państwa pełni inną rolę: broni przeciwko „innym”, służy jako mechanizm regulujący napływ imigrantów, reguluje ich dostęp do praw ekonomicznych i socjalnych. Szczególnie widać tę rolę obywatelstwa w momencie przekraczania granicy państwowej, gdzie wyraźnie jest wprowadzony przez państwo podział na obywateli i nie-obywateli. Obywatelstwo jest zatem uznawane przez państwo za akceptowalną metodę podziału i swego rodzaju dyskryminacji ludności zamieszkującej na jego terytorium ${ }^{6}$.

Obywatelstwo należy zatem zdefiniować jako udział ludzi na równych prawach we wspólnocie politycznej. Z przynależnością do tej wspólnoty wiążą się określone obowiązki oraz dostęp do dóbr i przywilejów. Obywatelstwo jednak nadal powiązane jest z przynależnością narodową, a element przynależności do określonego narodu jest nadal wyznacznikiem i przesłanką do domagania się obywatelstwa określonego kraju?.

Nie można bowiem pominąć elementu narodowości przy analizowaniu zagadnienia obywatelstwa. Narody istnieją i większość, jeśli nie wszyscy mieszkańcy państw identyfikują się z jakimś narodem, każdy człowiek ma wolę i chęć przynależności do określonego narodu, grupy ludzi. Naród inspiruje ludzi do lojalności i poświęcenia w imię określonego celu i idei.

Konstytucja Rzeczpospolitej Polskiej wprowadza wyraźne rozróżnienie na prawa obywatelskie i prawa cudzoziemca. Już w artykule 1 Konstytucji czytamy, iż Rzeczpospolita Polska jest dobrem wspólnym

6 Th. W. Simon, Ethnic Identity and Minority Protection, Plymouth 2012, s. 85-99

7 D. Kostakopoulou, The Future Governance of Citizenship, New York 2008, s. 1-3. 
wszystkich obywateli ${ }^{8}$. Ustrojodawca uznał zatem, iż państwo jako dobro, byt prawny, jest wyłączną własnością jej obywateli i tylko oni mogą korzystać z dobrodziejstwa, jakie daje ten byt. Kolejne odniesienie się do zagadnienia obywatelstwa znajduje się w art. 5, gdzie dokonano wyraźnego rozróżnienia pomiędzy obywatelem a cudzoziemcem. Obywatelem jest ten, kto w myśl art. 34 nabył obywatelstwo przez urodzenie z rodziców będących obywatelami polskimi, i tylko on ma prawo do opieki państwa w pełnym zakresie i bez żadnych ograniczeń. Państwo bowiem jest zobowiązane do ochrony swoich obywateli, gdy przebywają na jego terytorium oraz poza jego granicami. Podkreślenia wymaga także fakt, iż konstytucja polska rozróżnia między obywatelami narodowości polskiej i obywatelami innych narodowości, dając wyraźny priorytet narodowi polskiemu'. W rozumieniu ustrojodawcy bycie obywatelem to nie tylko prawo do posiadania określonych praw i korzyści, to także obowiązki wobec państwa. Pierwszym podstawowym obowiązkiem jest wierność państwu polskiemu, jego obrona, ponoszenie danin społecznych oraz ochrona środowiska naturalnego ${ }^{10}$. Państwo dając, stawia swoim obywatelom także wymagania.

Podsumowując powyższe rozważania, można jednoznacznie stwierdzić, iż państwa europejskie nadal preferują model obywatelstwa narodowego, gdzie prawo do jego posiadania i domagania mają osoby mogące wylegitymować się przynależnością do określonego narodu.

8 Konstytucja Rzeczpospolitej Polskiej z 2 kwietnia 1997 r., Dz. U. z 1997 r. nr 78, poz. 483, z 2001 r. nr 28, poz. 319; z 2006 r. nr 200, poz. 1471; z 2009 r. nr 114, poz. 946.

9 Art. 5, art. 34 I 35 Konstytucji Rzeczpospolitej Polskiej z 2 kwietnia 1997 r., Dz. U. Z 1997 r. nr 78, poz. 483, Z 2001 r. nr 28, poz. 319, z 2006 r. nr 200, poz. 1471, z 2009 r. nr 114, poz. 946.

10 Art. 82 do 86 Konstytucji Rzeczpospolitej Polskiej z 2 kwietnia 1997 roku, Dz. U. Z 1997 r. nr 78, poz. 483, z 2001 r. nr 28, poz. 319, z 2006 r. nr 200, poz. 1471, z 2009 r. nr 114, poz. 946. 
W przypadku braku możliwości wykazania określonego pochodzenia osoba ubiegająca się o nadanie określonego obywatelstwa musi udowodnić nowemu państwu swoją więź z nim i znajomość języka. Więź ta może mieć charakter ekonomiczny lub osobisty, ale musi istnieć. Dodatkowo osoba taka musi władać językiem kraju, którego obywatelstwo przyjmuje, oraz musi znać jego historię i zwyczaje ${ }^{11}$.

\section{Prawa cudzoziemca}

Cudzoziemiec, szczególnie ten, który jest zarazem emigrantem, jest postrzegany jako zagrożenie dla systemu ekonomiczno-socjalnego państwa. Państwo dąży zatem do ograniczenia wjazdu cudzoziemców oraz ich praw. Zasadą jest, iż prawa cudzoziemców na terenie określonego państwa regulowane są przez jego prawo wewnętrzne, niemniej jednak normuje je także prawo międzynarodowe ${ }^{12}$. Pojawia się pytanie: kim jest cudzoziemiec - obcokrajowcem czy uchodźcą?

Prawodawcy w większości krajów Europy przez wiele lat rozpoznawali jako dominującą zasadę nabycia obywatelstwa przez cudzoziemca tak zwane jus soli (prawo ziemi). Każde dziecko urodzone na terytorium danego państwa stawało się jego obywatelem. W momencie utraty związków z określonym terytorium dochodziło do utraty obywatelstwa i dana osoba stawała się w państwie cudzoziemcem ${ }^{13}$. W prawie polskim znana jest legalna definicja cudzoziemca, który jest definiowany jako każda osoba, która nie posiada obywatelstwa polskiego ${ }^{14}$. Zatem osoba

11 Ustawa z dnia 12 grudnia 2013 r. o cudzoziemcach, Dz.U. z 2018 r. poz. 2094 z poz. zm.

12 M. B. Dembour, When Humans Become Migrants, Oxford 2015, s. 251.

13 Citizenship Today. Global perspective and practices, red. T. A. Aleinikoff, D. Klusmeyer, Waszyngton 2000, s. 17-29.

14 Art. 3 ust. 2 Ustawy z dnia 12 grudnia 2013 r. o cudzoziemcach, Dz.U. z 2018 r. poz. $2094 \mathrm{Z}$ poz. Zm. 
z podwójnym obywatelstwem, niezależnie od tego, jakie obywatelstwo zadeklarowała w momencie wjazdu na terytorium Polski, nie będzie traktowana jak cudzoziemiec. Podobną definicję cudzoziemca znaleźć można także w innych aktach prawnych, np. w Ustawie o pomocy społecznej, gdzie w art 5 ust. 2 cudzoziemiec zdefiniowany jest przez pryzmat praw, jakie posiada, i poprzez status, jaki jest mu nadany, jednak zawsze w kontekście braku obywatelstwa ${ }^{15}$. Prawo międzynarodowe także posługuje się pojęciem „cudzoziemiec” w dwóch, trochę odmiennych, aspektach: w perspektywie przynależności narodowej, czyli rozpoznania siebie jako osoby należącej do konkretnego narodu lub grupy etnicznej, oraz w kontekście emigracji, gdy osoby zostały zmuszone lub z własnej woli opuściły państwo swojego dotychczasowego zamieszkania i przesiedliły się do innego kraju. Europejska Konwencja o Ochronie Praw Człowieka i Podstawowych Wolności $\mathrm{w}$ art. 16 zawiera pośrednią definicję cudzoziemca ${ }^{16}$. Państwom zostało bowiem przyznane prawo do ograniczenia wolności politycznej cudzoziemców, definiowanych jako osoby nieposiadające obywatelstwa państwa strony Konwencji. Analizując treść Konwencji, która z jednej strony każdemu człowiekowi bez wyjątku, przyznaje określony katalog praw i przywilejów, to jednak w stosunku do cudzoziemców, decyzją państw, ten katalog może zostać ograniczony ${ }^{17}$.

Prawa człowieka jako prawo nadrzędne znajduje swoją ochronę na szczeblu międzynarodowym poprzez orzecznictwo sądów/trybunałów praw człowieka. Ogólną zasadą wynikającą z prawa mię-

15 Ustawa z dnia 12 marca 2004 r. o pomocy społecznej, Dz. U. 2017.1769 t.j.

16 Art. 16 Ograniczenia działalności publicznej cudzoziemców: „Żadnego z postanowień [artykułów 10, 11 i 14] nie można uznać za wyłączające prawo Wysokiej Układającej się Strony do ograniczenia działalności politycznej cudzoziemców”. Konwencja o Ochronie Praw Człowieka i Podstawowych Wolności, sporządzona w Rzymie dnia 4 listopada 1950 r., zmieniona następnie Protokołami nr 3, 5 i 8 oraz uzupełniona Protokołem nr 2, Dz. U. 1993 nr 61 poz. 284.

17 M. B. Dembour, When Humans Become Migrants, dz. cyt., s. 58-6o. 
dzynarodowego jest norma zawarta w art. 14 Konwencji o Ochronie Praw Człowieka i Podstawowych Wolności ${ }^{18}$, wprowadzająca zasadę równego traktowania $\mathrm{w}$ takich samych okolicznościach obywatela i cudzoziemca, który legalnie przebywa na terytorium danego kraju. Zatem każdy cudzoziemiec, który znajduje się w takiej samej sytuacji prawnej i faktycznej jak obywatel danego państwa, powinien mieć zagwarantowane takie same prawa i korzyści ${ }^{19}$. Konwencja jak każdy akt prawny podlega wykładni, której dokonuje Europejski Sąd Praw Człowieka (ECHR), sprawujący w ramach swoich kompetencji ostateczny nadzór nad orzecznictwem sądów krajowych w zakresie przestrzegania praw człowieka. Sądy krajowe co do zasady uznają orzecznictwo ECHR jako wiążące, niemniej jednak w ostatnich latach sądy krajowe w kilku przypadkach zanegowały wyroki ECHR jako niekompatybilne z prawem krajowym i odmówiły jego zastosowania w ramach porządku krajowego. Szczególnie ważne jest to omówienie $\mathrm{w}$ tym miejscu, bowiem sądy krajowe zakwestionowały orzeczenia ECHR właśnie w sprawach dotyczących praw cudzoziemców. Europa nie jest bowiem jednomyślna, jeśli chodzi o uznawanie wyroków ECHR. Pierwsze podejście (reprezentowane przez Hiszpanię i Wielką Brytanię) to zasada bezwzględnego prawie posłuszeństwa w zakresie adaptacji orzeczeń ECHR do porządku prawnego. Drugie podejście, preferowane przez większość państw, to stanowisko pośrednie, kiedy orzeczenie jest implementowane, ale wyłącznie wtedy, gdy nie jest sprzeczne z konstytucją danego państwa. Jest to postrzegane jako dialog pomiędzy porządkiem prawnym wewnętrznym a prawem międzynarodowym. W ramach tego dialogu sądy krajowe zachowują prawo do nieuznawania orzeczeń ECHR i zastosowania wykładni krajowej.

18 Konwencja o Ochronie Praw Człowieka i Podstawowych Wolności, sporządzona w Rzymie dnia 4 listopada 1950 r., zmieniona następnie Protokołami nr 3, 5 i 8 oraz uzupełniona Protokołem nr 2, Dz. U. 1993 nr 61 poz. 284.

19 M. B. Dembour, When Humans Become Migrants, dz. cyt., s. 251. 
Takie podejście do orzecznictwa ECHR mają sądy polskie, niemieckie, włoskie i francuskie ${ }^{20}$.

Niemniej jednak orzecznictwo międzynarodowe znajduje coraz większe uznanie i prowadzi do ujednolicenia polityki państw na poszczególnych obszarach. W zakresie praw cudzoziemców takim przełomowym orzeczeniem jest wyrok w sprawie Gaygusuz v. Austria, który zapadł w 1996 roku $^{21}$. Powód, obywatel turecki, od wielu lat zamieszkały na terenie Austrii i zatrudniony tam na umowę o pracę, ze względów zdrowotnych w 1986 roku przerwał pracę i otrzymywał rentę w formie zasiłku dla bezrobotnych. Kiedy jego prawo do renty wygasło, zwrócił się do rządowej agencji pracy w Linzu o przyznanie mu doraźnej, interwencyjnej pomocy finansowej dla bezrobotnych. Świadczenie zostało mu odmówione ze względu na fakt, iż nie posiadał obywatelstwa austriackiego. Sprawa trafiła do ECHR, który orzekł, iż doszło do naruszenia art. 14 Konwencjii ${ }^{22}$, zgodnie z którym zakazana jest jakakolwiek forma dyskryminacji, w tym ze względu na pochodzenie narodowe lub społeczne $e^{23}$. Orzeczenie to jest uznawane za jedno z najważniejszych w doktrynie, głównie ze względu na fakt, iż sąd nie dokonując zbyt głębokiej analizy prawnej, zrównał na gruncie art. 14 cudzoziemca posiadającego prawo do legalnego pobytu w określonym państwie z prawami obywatela. W ocenie sądu państwo, które pozwoliło cudzoziemcowi przebywać na swoim terytorium i dopuściło go do świadczenia pracy, nie może odmówić mu prawa do zasiłku wyłącznie ze względu na fakt, iż nie posiada on

20 N. Krisch, Beyond Constitutionalism, the pluralistic structure of post national law, Oxford 2010, S.110-128,

21 Europejski Sąd Praw Człowieka, Gaygusuz v. Austria, nr 17371/9o, dnia 16.09.1996.

22 Europejski Sąd Praw Człowieka, Gaygusuz v. Austria, nr 17371/90, dnia 16.09.1996.

23 Konwencja o Ochronie Praw Człowieka i Podstawowych Wolności, sporządzona w Rzymie dnia 4 listopada 1950 r., zmieniona następnie Protokołami nr 3, 5 i 8 oraz uzupełniona Protokołem nr 2, Dz. U. 1993 nr 61 poz. 284. 
obywatelstwa austriackiego ${ }^{24}$. Orzeczenie to w sposób jednoznaczny zrównało w prawach obywatela i cudzoziemca, który legalnie przebywał na terytorium danego kraju. Na pytanie, czy w przypadku nielegalnego pobytu cudzoziemca orzeczenie byłoby takie samo, odpowiedź jest negatywna. Sąd dokonał porównania sytuacji faktycznej i prawnej obywatela i cudzoziemca, któremu państwo zezwoliło na pobyt na swoim terytorium i podjęcie pracy. W wyniku tej analizy sąd orzekł, iż wyłączną przeszkodą w otrzymaniu świadczenia był brak obywatelstwa. W ocenie sądu taka dyskryminacja jest niedopuszczalna $\mathrm{z}$ tego względu, iż cudzoziemiec świadcząc pracę, nabył prawo do określonego świadczenia i nie istnieją logiczne przesłanki do odmowy jego przyznania wyłącznie dlatego, iż nie jest on obywatelem państwa. W ocenie sądu dyskryminacja taka jest dopuszczalna wyłącznie wtedy, gdy przyznanie takiego prawa stanowiłoby zagrożenie dla bytu i integralności państwa ${ }^{25}$.

Innym orzeczeniem jest Hoti przeciwko Chorwacji ${ }^{26}$. Przedmiotowe orzeczenie dotyczyło pana Hoti, urodzonego w Kosowie z rodziców posiadających obywatelstwo albańskie, który jako bezpaństwowiec przez 40 lat zamieszkiwał na terenie Chorwacji. W wyroku sąd orzekł, iż Chorwacja dopuściła się naruszenia art. 8 Konwencji poprzez nieuregulowanie sytuacji prawnej pana Hoti, pomimo jego wyraźnego identyfikowania się z państwem chorwackim. W ocenie sądu obowiązkiem państwa jest uregulowanie statusu cudzoziemców, którzy przebywają na jego terytorium, szczególnie wtedy, gdy pobyt ich jest legalny ${ }^{27}$. Cudzoziemiec ma zatem prawo domagania się uregulowania jego statusu

24 Europejski Sąd Praw Człowieka, Gaygusuz v. Austria, nr 17371/90, dnia 16.09.1996.

25 Europejski Sąd Praw Człowieka, Gaygusuz v. Austria, nr 17371/90, dnia 16.09.1996.

26 Hoti v. Croatia, nr 63311/14, Europejski Sąd Praw Człowieka, rok wydania orzeczenia 2018, dnia 26 kwietnia.

27 Hoti v. Croatia, nr 63311/14, Europejski Sąd Praw Człowieka, rok wydania orzeczenia 2018, dnia 26 kwietnia. 
prawnego, a nawet - w pewnych okolicznościach - domagania się nadania mu obywatelstwa określonego państwa. Obywatelstwo jest bowiem powiązane $\mathrm{z}$ jednej strony $\mathrm{z}$ prawem jednostki do posiadania państwa, z drugiej strony z mocną identyfikacją danej osoby z określonym państwem, co prowadzi do domagania się od państwa przyznania jej obywatelstwa jako członkowi społeczności ekonomicznej, językowej, a także kulturowej ${ }^{28}$.

Prawo do obywatelstwa nie stanowi zatem prawa dla cudzoziemca do jego domagania się i nie należy do praw człowieka objętych ochroną Europejskiej Konwencji Praw Człowieka, jednak w sytuacji, gdy odmowa nadania obywatelstwa lub nieuznanie praw cudzoziemca narusza inne prawa podstawowe, jak prawo do godnego życia (Gaygusuz), prawo do życia rodzinnego (Hoti), państwo zobowiązane jest do podjęcia odpowiednich kroków, które usuną zagrożenia lub nawet naruszenie praw człowieka. Obowiązkiem państwa jest bowiem przestrzeganie praw człowieka na swoim terytorium i eliminowanie wszelkich zagrożeń dla ich poszanowania ${ }^{29}$.

\section{Podsumowanie}

Przedstawiona powyżej analiza definicji obywatelstwa oraz cudzoziemca prowadzi do jednoznacznego wniosku, iż prawo krajowe, jak i prawo międzynarodowe różnicuje ludzi pod względem posiadania obywatelstwa i że dopuszczalna jest na gruncie prawa nierówność statusu prawnego i różnicowanie ludzi przez państwo ze względu na to, czy posiadają oni, czy nie posiadają obywatelstwa tego państwa. Jed-

28 H. Lambert, Nationality and Statelessness Before the European Court of Human Rights: A landmark judgment but what about Article 3 ECHR?, https://strasbourgobservers. com/2018/05/16/nationality-and-statelessness-before-the-european-court-of-human-rights-a-landmark-judgment-but-what-about-article-3-echr/ (26.05. 2018).

Ramada v. Malta, nr 76136/12, Europejski Sąd Praw Człowieka, dnia 21 czerwca 2016. 
nakże to zróżnicowanie nie powinno w żadnym przypadku prowadzić do naruszenia praw człowieka, bowiem na tej płaszczyźnie prawo nie dopuszcza żadnej dywersyfikacji i zrównuje ludzi bez względu na ich pochodzenie, narodowość czy obywatelstwo. Zatem tak długo, jak długo państwo dywersyfikuje w prawach obywateli i cudzoziemców, nie naruszając praw człowieka, jest to dopuszczalna dychotomia. Jest ona dozwolona także wtedy, gdy przemawia za tym słuszny interes państwa i jego obywateli.

\section{Streszczenie}

Obywatelstwo jest postrzegane powszechnie jako prawo zależne od decyzji państwa i uregulowane $\mathrm{w}$ wewnętrznym porządku prawnym. Regulowanie zasad nabywania obywatelstwa oraz proces naturalizacji pozostają w wyłącznej kompetencji państwa. Państwo z oczywistych względów faworyzuje swoich obywateli, przyznając im szeroki wachlarz praw i przywilejów. Zarazem obywatelstwo jest postrzegane jako narzędzie kontroli osób, które napływają do państwa, i określenie ich praw i zasad osiedlania się w państwie. Dla większości z nas obywatelstwo jest czymś tak oczywistym, iż nie zastanawiamy się nad jego znaczeniem czy obowiązkami państwa. W państwie zamieszkują nie tylko osoby, które posiadają obywatelstwo, ale także osoby o nieustalonym stanie prawnym, osoby ubiegające się o azyl oraz osoby posiadające status rezydenta. Państwo jako takie jest zainteresowane obecnością tych osób w państwie. Zainteresowanie państwa jest tak istotne, iż osobom tym przyznawane są określone prawa i przywileje. Zakres nadanych im praw jest jednak inny, zazwyczaj mniejszy, niż ten, który posiadają obywatele. Na gruncie praw człowieka pojawia się jednak pytanie, czy państwo jest uprawnione do przyznawania i rozpoznawania praw człowieka w zależności od tego, czy dana osoba posiada obywatelstwo, czy go nie posiada. Skoro państwo posiada prawo do rozróżniania statusu prawnego obywatela i cudzoziemca, to czy ta prerogatywa nie powinna być ograniczona na gruncie praw człowieka? Czy państwo nie dopuszcza się zatem dyskryminacji ze względu na pochodzenie?

Słowa kluczowe: prawa człowieka, cudzoziemcy, emigranci, państwo, obywatele 


\section{Summary}

Rights of the citizen, and rights of foreigner? Dylema of XXI century state

Citizenship is widely recognised right govern by the states and used by the states to mange the influx of the people to and from the state. Citizenship is used by the state as a tool to control its obligation towards the people who declared the belonging to the state or habited in the state boarders. So for the most of us the citizenship is normal out of the question rights and associate with it state obligation. On the other hand for the state it can be see as burden sometimes unnecessary and costly. This is major reason why, when drafting international regulation concerning the human rights the right to citizenship was almost forgotten and left to the state to regulate it. As said with the citizenship comes rights and some obligation. But in the state borders reside not only the solo citizens they are immigrants, residents or asylum seekers. State is is also interested in them and on some particular occasion grants them some rights and obligation. However the modern approach to the human forces state to level up the citizens and foreigners in they rights. Is not difficult to understood state are not willing to do this. That is why it is necessary to answer on the question if the states have right to differentiate citizens and foreigners in any situation on the grounds of human rights? They both are human. They both posses this same rights associated with they status as the human being, so why state is allowed to treat them different because of the state internal regulation?

Key words: human rights, nation, citizenship, immigration, ethnicity 